\title{
Review Article \\ Denture Liners: A Systematic Review Relative to Adhesion and Mechanical Properties
}

\author{
Simone Kreve and Andréa C. Dos Reis \\ Department of Dental Materials and Prosthodontics, Ribeirão Preto Dental School, University of São Paulo (USP), Ribeirão Preto, \\ SP, Brazil \\ Correspondence should be addressed to Andréa C. Dos Reis; andreare73@yahoo.com.br
}

Received 11 November 2018; Revised 25 January 2019; Accepted 13 February 2019; Published 3 March 2019

Academic Editor: Giovanna Orsini

Copyright (C) 2019 Simone Kreve and Andréa C. Dos Reis. This is an open access article distributed under the Creative Commons Attribution License, which permits unrestricted use, distribution, and reproduction in any medium, provided the original work is properly cited.

\begin{abstract}
Purpose. The objective of this systematic review is to compare results concerning the properties of adhesion, roughness, and hardness of dental liners obtained in the last ten years. Methods. Searches on the databases LILACS, PubMed/Medline, Web of Science, and Cochrane Database of Systematic Reviews were supplemented with manual searches conducted between February and April of 2018. The inclusion criteria included experimental in vitro and in vivo, clinical, and laboratory studies on resilient and/or hard liners, assessment of hardness, roughness, and/or adhesion to the denture base, and physical/mechanical changes resulting from the disinfection process and changes in liners' composition or application. Results. A total of 406 articles were identified and, from those, 44 are discussed. Twenty-four studies examined the bond strength, 13 surface roughness, and 19 the hardness. Of these 44 studies, 12 evaluated more than one property. Different substances were used in the attempt to improve adhesion. Considering roughness and hardness, the benefits of sealants have been tested, and the changes resulting from antimicrobial agents' incorporation have been assessed. Conclusion. Adhesion to the prosthesis base is improved with surface treatments. Rough surfaces and changes in hardness compromise the material's serviceability.
\end{abstract}

\section{Introduction}

Liners have been widely used in dentistry to reshape prostheses surfaces in contact with soft tissues of the oral cavity [1]. Failure in adhesion, rough surfaces, and changes in hardness are favorable factors for microbial accumulation and compromise the liner's durability and the oral health condition such as denture stomatitis [2], implant loss [3, 4], peri-implantitis [4], and osseointegration delay, as well as respiratory problems [5] that can interfere with the rehabilitation treatment success and quality of life.

Liners are also used for prostheses fractures, remodeling of bone crests [6-8], and cleft palate [9], in cases of excessive resorption of the alveolus and occurrence of lesions on the mucosa $[9,10]$, and in tissue conditioning during implant healing [11], among others, acting to dissipate part of the impact of mastication $[8,12]$. They are processed in laboratories (heat-polymerized) [13] and/or dentist offices (selfpolymerized) because of their easy and quick application
[14-17]. The term "soft liners" refers to a class of resilient materials used to reline denture base surfaces in contact with the occlusal stress-bearing oral mucosa [18].

Liners can be either hard $[6,16]$, usually made of polymethylmethacrylate $[9,10,19,20]$, or resilient [20-24], when plasticizers are added to the resin and the silicone elastomers $[22,24,25]$. Resilient liners are intended to be elastic, absorb energy, and act on the cushion effect [24]. Resilient reline materials are also classified as short- or long-term products. Long-term resilient denture liner materials maintain their resilience for more than 30 days and can be used for up to 1 year, while short-term liners are recommended for use for up to 30 days [26].

Liners are noninvasive and relatively more economical if compared to make a new denture $[23,27,28]$. Patients prefer resilient liners over the hard ones, because they improve comfort $[14,21,28,29]$.

However, they have some disadvantages, like presence of surface defects and porosity, residual taste after use, tendency 
to pick up odors $[14,30]$, water uptake $[14,24,31]$, poor adhesion to acrylic resin $[9,31]$, proneness to change of color $[7,23]$, difficulty to clean [32], and premature hardening due to plasticizers' solubilization $[10,31]$.

A successful relining depends on the bond strength between the liner and the resin base $[1,6,33,34]$. The lack of bonding leads to debonding, diminishing the procedure's longevity, and may occur due to an inefficient bond to the denture, or low cohesive strength [31]. According to Ahmad et al. [1], better adhesion is obtained when the materials' chemical properties are similar. Adhesion of liners to base polymers depends on the chemical composition of materials involved [19] and is influenced by the resin type, thermal cycle, and surface treatment [19, 31]. Excessive roughness results in microbial colonization and difficult hygiene. Liners are unstable in aqueous solutions; the hardness increases after water, saliva, and cleaning agents' absorption. Denture relining can be a factor of predisposition for prosthetic stomatitis.

The sealants' application [28, 29], surface treatments $[35,36]$, and physical-mechanical changes resulting from disinfection [17, 32, 37], among others, improve adhesiveness, reduce roughness, and maintain the liners' initial hardness.

Based on what has been presented, preserving the liners' physical-mechanical properties is a challenge. Considering its immediacy, simplified process, and economy, since the relining allows the use of the same prosthesis, it could be expected to grow demand especially more in dependent elderly care. This subject approach through a systematic review allows analyzing many studies' outcomes that have been carried out in attempt to improve these materials' limitations, such as debonding of denture base and changes in roughness and hardness that compromise its elasticity, assisting the clinicians in choosing the best product or technique. This systematic review covers studies published in the past 10 years aiming to assess the state of the art of liners, properties of adhesion, roughness, and hardness.

\section{Materials and Methods}

The question posed was as follows: Do the denture liners' modifications alter the adhesion, roughness, and hardness properties?

This systematic review was conducted according to the PRISMA (Preferred Reporting Items for Systematic Reviews and Meta-Analyses) report [38, 39] and registered on the PROSPERO database: CRD42018108821.

The review question, objectives of the study, eligibility criteria, and search and data analysis strategy were clearly stated in advance and incorporated in the protocol's content.

\subsection{Defining Eligibility Criteria}

2.1.1. Search Methods. Studies reporting the properties of adhesion, roughness, and hardness of dental liners were identified by searching electronic databases and scanning reference lists of articles. Four databases were searched, LILACS, PubMed/Medline, Web of Science, and Cochrane Database of
Systematic Reviews, using the following keywords: "denture liner" OR "reline" AND "soft liner" OR "surface roughness" OR "bond strength" OR "hardness" OR "hard liner."

The literature survey was conducted from February to April of 2018 and included articles published between 2008 and 2018, in the Journal Citation Reports (JCR) indexed journals. This period was chosen for the review since the articles within that time interval depict the results of the main findings previously. Supplemental searches were conducted; the reference and citations' lists of the selected papers were reviewed in order to select potential inclusions.

2.1.2. Types of Interventions. This systematic review was performed to answer the following questions: In patients wearing removable prostheses fitted with denture liners, does the bond strength of those materials alter? What has been used in the past 10 years to improve adhesion of denture liners to denture base? Do the modifications in the denture liners to improve the adhesion to the base of the prosthesis impair hardness and roughness values?

2.1.3. Comparison. This study compares with the standard treatment, which in this case is applying the liner according to the manufacturer's instructions.

2.1.4. Outcome Measures. The outcome measures were the effect of the intervention (denture liner) with some modification, as well as comparison between the effects of surface treatments with different substances on the properties of adhesion, roughness, and hardness. The main outcomes were defined when the article included in this review presented some adhesion, surface roughness, or/and hardness evaluation and showed a substantial result.

2.1.5. Types of Studies. We selected and assessed papers published in English that met the inclusion criteria: experimental in vitro and in vivo, clinical, and laboratory studies on resilient and/or hard liners, assessment of hardness, roughness, and/or adhesion to the denture base, and physical/mechanical changes resulting from the disinfection process and changes in liners' composition or application.

Studies based exclusively on materials for denture base, unpublished data, critiques, case reports, and expert opinion papers should be excluded due to their high risk of bias [38]. Systematic reviews should also not be included.

2.1.6. Study Selection. The study selection was carried out independently by two authors who adhered to the predefined eligibility criteria. Any disagreements between the two reviewers regarding the inclusion of studies were resolved by discussion.

2.1.7. Assessment of Bias in Individual Studies. Risks were minimized by strictly following the keywords, the coherence of the selected abstracts, and analysis of articles published in selective editorial policy journals; this guarantees the quality of the individual studies. 


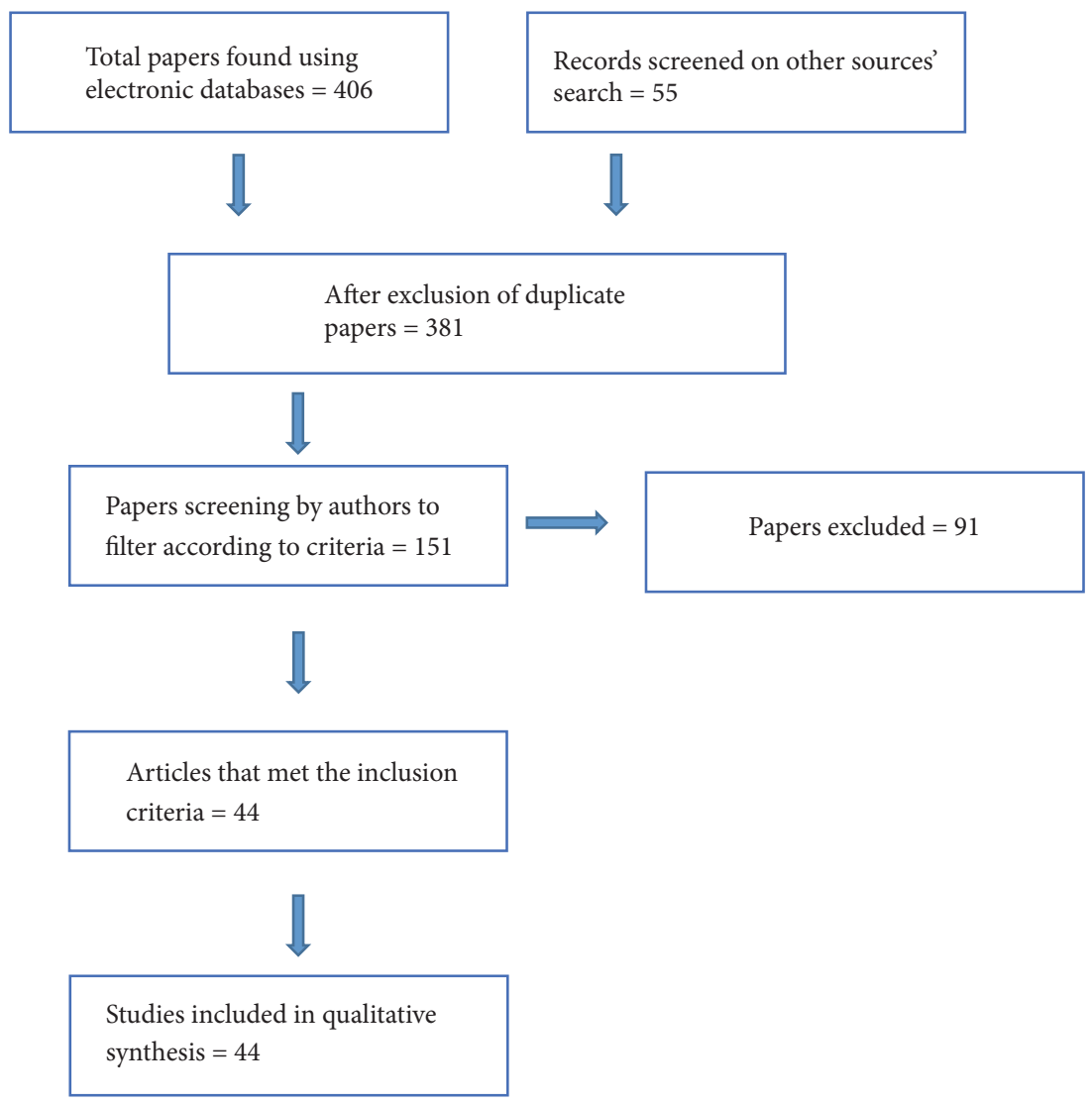

FIGURE 1: Flow of information through the different phases of the systematic review.

Each of the included studies was then assessed for potential internal methodological bias such as the adequacy of randomization, incomplete outcome, and appropriate method of blinding.

\section{Results}

A total of 406 studies were identified on the initial screening. All abstracts were analyzed according to the PRISMA statement $[38,39]$. Publications were identified as being relevant through the initial screening of titles and abstracts followed by screening of the full text. After exclusion of duplicates, 151 articles were selected for a complete assessment and, from these, 44 are discussed (Figure 1, Tables 1, 2, 3, and 4). Twenty-four studies examined the bond strength, 13 surface roughness, and 19 the hardness. Of these 44 studies, 12 evaluated more than one property. Most studies comprised in vitro evaluations, and only 3 were in vivo studies $[25,41,42]$.

The articles were subdivided into categories since each article could address more than one property $[8,17,19,27$, 29, 34, 35, 41, 43-45].

Considering the different commercial brands, Ufi Gel (VOCO) was the most commonly employed siliconebased liner, and Trusoft (BOSWORTH) was the most commonly employed resilient resin-base liner. Tokuyama Rebase II (Tokuyama) was the most used chairside hard liner.

Other materials such as Kooliner (GC America), Reline Soft (GC America), COE-SOFT (GC America), Sofreliner (Tokuyama), Mucopren Soft (Kettenbach), Elite Soft (Zhermack), and New Truliner (BOSWOTH) were also assessed often $[1,6,12,23,25,27,37,40,41,43,46-48]$.

Types of intervention were as follows: comparison between the effects of surface treatments with different substances [12, 20, 35, 36, 49], bond tests between liners and different prosthetic materials [1, 10, 31], and assessment of the initial roughness of materials and that resulting from disinfection methods $[17,32,44]$.

\section{Discussion}

Denture liners' materials have been widely used despite their substantial shortcomings. The use of solvents seems to improve the adhesion of the reliner to the PMMA base. Most cleansing agents compromise the hardness and elastic modulus. In addition, changes in roughness can lead to microbial colonization, increase the risk of oral and systemic infections, and decrease quality of life. Among the various disinfection methods, minor changes in the hardness and 
TABLE 1: Included studies related to the bond strength.

\begin{tabular}{|c|c|c|c|}
\hline Author/year & Method & Study objectives & Outcomes \\
\hline Ahmad et al./2009 & Shear bond strength & $\begin{array}{l}\text { Bond strength, denture to reline } \\
\text { materials }\end{array}$ & $\begin{array}{l}\text { Higher bond strengths with similar } \\
\text { compositions. PMMA (Meliodent), } \\
\text { highest bond strength with } \\
\text { (Meliodent RR), and UDMA } \\
\text { (Eclipse) with Eclipse reline }\end{array}$ \\
\hline Lassila et al./2010 & Tensile bond strength & $\begin{array}{c}\text { Bond strength, liners to } \\
\text { fiber-reinforced and unreinforced } \\
\text { PMMA }\end{array}$ & $\begin{array}{l}\text { Sofreliner Tough, highest bond } \\
\text { strength, and Eversoft, lowest }\end{array}$ \\
\hline $\begin{array}{l}\text { Więckiewicz et } \\
\text { al./2014 }\end{array}$ & Tensile and shear bond strength & $\begin{array}{l}\text { Adhesion of silicone lining to denture } \\
\text { base }\end{array}$ & $\begin{array}{l}\text { A-Soft Line } 30 \text {, the best adhesive } \\
\text { properties }\end{array}$ \\
\hline Mese and Guzel/2008 & Tensile bond strength & $\begin{array}{l}\text { Effect of storage on bond strength } \\
\text { and hardness, resilient liners }\end{array}$ & $\begin{array}{l}\text { Bond strength, lower as storage time } \\
\text { increased. Greater changes, acrylic } \\
\text { resilient liner }\end{array}$ \\
\hline Atsü and Keskin/2013 & Tensile bond strength & $\begin{array}{l}\text { Bond strength, silicone denture liner, } \\
\text { effects of surface treatment after } \\
\text { thermocycling }\end{array}$ & $\begin{array}{l}\text { Highest bond strength with adhesive. } \\
\text { Surface treatment did not improve } \\
\text { bond strength }\end{array}$ \\
\hline Santawisuk et al./2013 & Tensile bond strength & $\begin{array}{c}\text { Comparing experimental silicone } \\
\text { with lining materials }\end{array}$ & $\begin{array}{c}\text { Silastic }^{\circledR} \text { MDX4-4210 silicone, greater } \\
\text { mechanical properties }\end{array}$ \\
\hline Ohkubo et al./2009 & Shear bond strength & $\begin{array}{l}\text { Bond strength immersing denture in } \\
\text { methylmercaptan }\end{array}$ & $\begin{array}{c}\text { Methylmercaptan causes liner } \\
\text { detachment }\end{array}$ \\
\hline Takahashi et al./2011 & Tensile bond strength & $\begin{array}{l}\text { Accelerated aging times on bond } \\
\text { strength of soft liners }\end{array}$ & $\begin{array}{c}\text { Mucopren Soft, higher tensile bond } \\
\text { strength than Trusoft }\end{array}$ \\
\hline Hamanaka et al./2016 & Shear bond strength test & $\begin{array}{l}\text { Bond strength of reline resin to } \\
\text { injection-molded thermoplastic } \\
\text { denture }\end{array}$ & $\begin{array}{c}\text { Bond strengths' values varied. Bond } \\
\text { improved, tribochemical silica } \\
\text { coating and 4-META/MMA-TBB } \\
\text { resin }\end{array}$ \\
\hline Cavalcanti et al./2014 & Tensile bond strength & $\begin{array}{l}\text { Surface treatments on adhesion of } \\
\text { silicone denture liners }\end{array}$ & $\begin{array}{c}\text { Methylmethacrylate and ethyl acetate } \\
\text { improved the adhesion of a silicone } \\
\text { denture liner to PMMA }\end{array}$ \\
\hline Kim et al./2014 [33] & Tensile bond strength & $\begin{array}{l}\text { Bond strength, long-term soft } \\
\text { denture lining }\end{array}$ & $\begin{array}{l}\text { GC Reline Soft, highest bond } \\
\text { strength. GC Reline Ultrasoft and } \\
\text { Mucopren Soft, the lowest }\end{array}$ \\
\hline Kanie et al./2009 & $\begin{array}{l}\text { Tensile bond strength and adhesive } \\
\text { strength }\end{array}$ & $\begin{array}{l}\text { Physical/mechanical properties, } \\
\text { experimental light-curing soft lining }\end{array}$ & $\begin{array}{c}\text { Tensile strength of UV-37, the lowest. } \\
\text { No difference in adhesive strength } \\
\text { between UV-35 and UV-37 at } 1 \text { day } \\
\text { and } 12 \text { months }\end{array}$ \\
\hline Dayrell et al./2012 & Tensile bond strength & $\begin{array}{l}\text { Bond strength and surface roughness } \\
\text { of soft liners, sealer coating }\end{array}$ & $\begin{array}{l}\text { Without surface sealer Mucopren } \\
\text { Soft and Dentuflex, highest bond } \\
\text { strength; Ufi Gel, intermediate; and } \\
\text { Comfort Denso, the lowest }\end{array}$ \\
\hline Takahashi et al./2009 & Flexural strength test & $\begin{array}{c}\text { Microwave postpolymerization (PP) } \\
\text { on strength, acrylic resin intact and } \\
\text { relined }\end{array}$ & $\begin{array}{l}\text { New Truliner, smaller strength with } \\
\text { PP microwave and effective only for } \\
\text { Kooliner }\end{array}$ \\
\hline Kim et al./2014 [40] & $\begin{array}{l}\text { Tensile bond strength and transverse } \\
\text { bond strength }\end{array}$ & $\begin{array}{c}\text { Bond strength, relining resins, } \\
\text { Acrytone, comparison, } \\
\text { heat-polymerized acrylic and } \\
\text { polyamide }\end{array}$ & $\begin{array}{l}\text { Bond strength, reline resins and } \\
\text { thermoplastic denture similar to } \\
\text { acrylic resin. Polyamide, lowest }\end{array}$ \\
\hline Maeda et al./2012 & Peel bond strength & $\begin{array}{c}\text { Bond of resilient denture liners to } \\
\text { denture }\end{array}$ & $\begin{array}{l}\text { All, adequate bond strength, used } \\
\text { clinically for three years }\end{array}$ \\
\hline Tanimoto et al./2009 & Peel bond strength & Adhesive denture and denture liner & GC Reline Ultrasoft, lower adhesion \\
\hline $\begin{array}{l}\text { Koodaryan and } \\
\text { Hafezeqoran/2016 }\end{array}$ & Shear bond strength test & $\begin{array}{c}\text { Bond strength, reline resin, } \\
\text { polyamide and surface modification, } \\
\text { acetic acid }\end{array}$ & $\begin{array}{l}\text { Acetic acid, the greatest bond } \\
\text { strength of MMA }\end{array}$ \\
\hline
\end{tabular}


TABLe 1: Continued.

\begin{tabular}{lccc}
\hline Author/year & Method & Study objectives & Outcomes \\
\hline $\begin{array}{l}\text { Osathananda and } \\
\text { Wiwatwarrapan/2014 }\end{array}$ & Shear bond strength test & $\begin{array}{c}\text { Bond strength, denture-reline resins, } \\
\text { methyl formate-methyl acetate } \\
\text { (MF-MA) }\end{array}$ & $\begin{array}{c}\text { MF:MA ratio 25:75, enhances bond } \\
\text { strength, denture and UNIFAST } \\
\text { Trad, or Ufi Gel Hard }\end{array}$ \\
\hline Akin et al./2013 & Tensile bond strength & $\begin{array}{c}\text { Bond strength, silicone denture liner, } \\
\text { surface treatments }\end{array}$ & $\begin{array}{c}\text { Denture base, silicone liner, similar } \\
\text { bond strength. Lasing Eclipse resin, } \\
\text { increased bond strength }\end{array}$ \\
\hline Pisani et al./2009 & Tensile bond strength & $\begin{array}{c}\text { Sodium perborate, bond strength, } \\
\text { degree infiltration, acrylic } \\
\text { resin/denture liners }\end{array}$ & $\begin{array}{c}\text { Kooliner, no difference in bond } \\
\text { strength, immersion or sodium } \\
\text { perborate. }\end{array}$ \\
\hline Alcântara et al./2012 & Peel bond strength & $\begin{array}{c}\text { Mucopren Soft, highest tension, and } \\
\text { Elite Soft the lowest }\end{array}$ \\
\hline Chladek et al./2013 & Tensile bond strength & Silver nanoparticle into denture liners \\
liner, denture & $\begin{array}{c}\text { Antimicrobial did not affect bond } \\
\text { strength, resilient liner and denture }\end{array}$ \\
\hline
\end{tabular}

roughness properties were observed when incorporating antimicrobial agents into the liners.

4.1. Denture Liner Adhesion Mechanism. Aging [1] alters the adhesive properties of denture base polymers and liners [49] leading to flaws on the materials interface $[41,49,50]$.

The bond between the prosthesis and liner begins with the dissolution of the resin by the solvent, swelling of surface layers, and evaporation of the solvent. The liner monomers diffuse, penetrate the resin pores, and form an interpenetrating polymeric network [51]. The larger the surface swelling, the deeper the porous layer and, as a consequence, the better the adhesion between the liner and denture base.

The bond strength between the liner and denture base was assessed $[12,15,31,49,50]$ through primer application, where the layer of the GC resin primer was applied on the polyamide surfaces [52], through an adhesive such as a bonding agent that is a reline material partner [12], through sandblasting of the acrylic base resin surfaces with $50 \mu \mathrm{m} \mathrm{Al}{ }_{2} \mathrm{O}_{3}$ particles [20], through organic solvents, such as the application of an acetone solution and ethyl acetate solution [35], through application of a mixture of methyl formate and methyl acetate solution [51], and with changes in the prosthesis material like PMMA, preimpregnated with unidirectional glass fiber [12].

According to Ohkubo et al. [30], dentures used for an extended period of time are difficult to reline because microorganisms produce methyl mercaptan, which causes liner detachment even after the primer dissolution. Since bacteria penetrate to approximately $3 \mathrm{~mm}$ deep [30], more efficacy is obtained by reducing the base thickness and applying a high penetration primer, such as those based on dichloromethane.

4.1.1. Silicone Liners. Silicone liners are mechanically superior and more durable than resin liners [35, 43]. However, they lack chemical adhesion $[19,31,35]$, and adhesive flaws can be associated with the bonding agent [12]. Adhesive failures between the liner (silicone-type resilient denture liners) and prosthesis (heat-polymerized polymethylmethacrylate (PMMA)) increased from $13.8 \%$ to $60 \%$ after 30 days of storage in water [49], suggesting that their bonding gradually weakens over time.

Air abrasion with silica and silanization failed to improve bond strength of silicone resilient lining to the prosthesis (heat-cure acrylic), and the defects produced by the $30 \mu \mathrm{m}$ particles were not sufficient for the liner material penetration [20].

Organic solvents such as MMA (methylmethacrylate) and ethyl acetate improve silicone liners' adhesion to PMMA because they lead to softening and porosities that enhance adhesive penetration [33, 35]. Lassila et al. [12] found enhanced adhesion using ethyl acetate as bonding agent; Kim et al. [40] found better results using a primer or adhesive to adhere silicone liners to PMMA surfaces since they reduce the bubbles' formation during relining.

\subsubsection{Treatments to Improve Denture Liners' Adhesion to} the Prosthesis. Treatment with acetic acid was comparable to that with tribochemical silica coating [52]. On the other hand, polymethylmethacrylate (PMMA) surfaces showed better adhesion with methyl formate-methyl acetate (MF-MA) than with resin liner bonding agents [51], composed of acetone and 2-HEMA, which is not volatile and obstructs the polymeric chains' interlocking, thus reducing bonding. There is no residual solution for MF-MA.

Another way to enhance the liners' adhesion to the prostheses is application of laser Er: YAG that alters prostheses surfaces, creating defects. Akin et al. [53] showed an increase in the silicone-based liners' bond strength to a UDMA base following laser application. 
TABLE 2: Included studies related to the hardness and roughness for soft denture liners.

\begin{tabular}{|c|c|c|c|}
\hline Author/year & Method used & Study objectives & Outcomes \\
\hline Kasuga et al./2011 & $\begin{array}{l}\text { Hardness values in Shore A } \\
\text { durometer }\end{array}$ & $\begin{array}{l}\text { Compare fluorinated monomer soft } \\
\text { lining materials, conventional }\end{array}$ & $\begin{array}{l}\text { No hardness difference, experimental } \\
\text { fluorinated soft lining materials, } \\
\text { Molloplast B }\end{array}$ \\
\hline Mese and Guzel/2008 & $\begin{array}{l}\text { Hardness values in Shore A } \\
\text { durometer }\end{array}$ & $\begin{array}{l}\text { Storage duration on tensile bond } \\
\text { strength and hardness, acrylic resin } \\
\text { and silicone liners }\end{array}$ & $\begin{array}{l}\text { Hardness, higher with increased } \\
\text { duration of immersion }\end{array}$ \\
\hline Santawisuket al./2013 & $\begin{array}{l}\text { Hardness values in Shore A } \\
\text { durometer }\end{array}$ & $\begin{array}{c}\text { Tensile strength, tear resistance, and } \\
\text { hardness of experimental silicone } \\
\text { elastomers (ESE) }\end{array}$ & $\begin{array}{c}\text { Hardness, ESE increased with } \\
\text { amount of silica filler (from } 6 \text { to } 10 \\
\text { phr) }\end{array}$ \\
\hline Kutlu et al./2016 & Surface roughness tester & $\begin{array}{l}\text { Sealer coating, roughness of soft } \\
\text { lining }\end{array}$ & $\begin{array}{l}\text { Roughness, methacrylate-based } \\
\text { liners increased, denture cleanser. } \\
\text { Sealer coating, no effect, roughness }\end{array}$ \\
\hline Mante et al./2008 & $\begin{array}{c}\text { Hardness values in Shore A } \\
\text { durometer }\end{array}$ & PermaSeal, hardness of soft reline & $\begin{array}{l}\text { Sealer reduced saliva softening effect, } \\
\text { methacrylate-based soft reline }\end{array}$ \\
\hline Kim et al./2014 [33] & $\begin{array}{l}\text { Hardness values in Shore A } \\
\text { durometer }\end{array}$ & $\begin{array}{l}\text { Hardness and bond strength of } \\
\text { long-term soft denture lining }\end{array}$ & $\begin{array}{l}\text { Hardness, 28-day increased } \\
\text { compared to 24-hour }\end{array}$ \\
\hline Kanie et al./2009 & $\begin{array}{c}\text { Hardness values in Shore A } \\
\text { durometer }\end{array}$ & $\begin{array}{c}\text { Evaluate experimental light-curing } \\
\text { soft lining materials (ESLMs) }\end{array}$ & $\begin{array}{l}\text { Hardness, UA-16, UV-32, and UV-35 } \\
\text { similar to commercial denture liner }\end{array}$ \\
\hline Badaró et al./2017 & $\begin{array}{c}\text { Hardness values in Shore A } \\
\text { durometer and surface roughness } \\
\text { tester }\end{array}$ & $\begin{array}{l}\text { R. communis dentifrice }(10 \%) \text { on } \\
\text { abrasiveness, hardness, and color } \\
\text { change of a denture liner }\end{array}$ & $\begin{array}{l}\text { Weight loss, roughness similar to } \\
\text { Corega. Colgate, Corega Brite, } \\
\text { roughness from } 0.26 \text { to } 0.34 \mu \mathrm{m} \text {. } \\
\text { Brushing, no effect, hardness }\end{array}$ \\
\hline Dayrell et al./2012 & Surface roughness tester & $\begin{array}{l}\text { Sealer coating, bond strength and } \\
\text { roughness of liners }\end{array}$ & $\begin{array}{l}\text { Palaseal coating, no effect, liners } \\
\text { roughness. Without sealer coating, } \\
\text { no difference observed on roughness }\end{array}$ \\
\hline Machado et al./2012 & Surface roughness tester & $\begin{array}{l}\text { Roughness of denture resin, hard and } \\
\text { resilient lining materials }\end{array}$ & $\begin{array}{l}\text { No differences, initial roughness, } \\
\text { Lucitone, Sofreliner, Tokuyama } \\
\text { Rebase II, and New Truliner. } \\
\text { Immersion } 4 \% \text {, chlorhexidine } \\
\text { increased roughness. Ufi Gel Hard } \\
\text { and Sofreliner, after } 1 \text { and } 2 \\
\text { disinfection cycles }\end{array}$ \\
\hline Cazacu et al./2009 & $\begin{array}{c}\text { Hardness values in Shore A } \\
\text { durometer }\end{array}$ & Heat curable silicone, tested as a liner & Hardness, 59 ShA \\
\hline
\end{tabular}

Mainieri et al./2011 Surface roughness tester

Roughness, soft liners with and increased baseline, 1 month. Ufi-Gel without surface sealer after brushing with and without sealer coating, after 6 months

Roughness, Tokuyama Rebase II and

Ufi Gel Hard similar or > New

Machado et al./2011 Surface roughness tester

Roughness denture, hard and resilient lining materials

Truliner. Lucitone and Tokuyama

Rebase II, no affected immersion desinfection

\begin{tabular}{|c|c|c|c|}
\hline & & & \\
\hline Mancuso et al./2012 & $\begin{array}{l}\text { Hardness values in Shore A } \\
\text { durometer }\end{array}$ & $\begin{array}{l}\text { Ageing effect, hardness, absorption, } \\
\text { solubility, and color denture liners }\end{array}$ & Thermocycling influenced hardness \\
\hline Leite et al./2010 & $\begin{array}{l}\text { Hardness values in Shore A } \\
\text { durometer }\end{array}$ & Hardness values & $\begin{array}{l}\text { Thermal cycling increased hardness, } \\
\text { Elite Soft. Decrease for Kooliner }\end{array}$ \\
\hline Pisani et al./2012 & $\begin{array}{c}\text { Hardness values in Shore A } \\
\text { durometer and surface roughness } \\
\text { tester }\end{array}$ & $\begin{array}{c}\text { Color stability, hardness and } \\
\text { roughness, denture liners cleansers' } \\
\text { immersion }\end{array}$ & $\begin{array}{c}\text { Hardness increased. Hypochlorite } \\
\text { altered hardness. Elite Soft, highest } \\
\text { roughness }\end{array}$ \\
\hline Bertolini et al./2014 & $\begin{array}{l}\text { Hardness values in Shore A } \\
\text { durometer }\end{array}$ & $\begin{array}{c}\text { Hardness, chlorhexidine diacetate or } \\
\text { chlorhexidine hydrochloride soft } \\
\text { lining }\end{array}$ & $\begin{array}{c}\text { Hardness, no changes, antimicrobial } \\
\text { agents }\end{array}$ \\
\hline Chladek et al./2013 & $\begin{array}{l}\text { Hardness values in Shore A } \\
\text { durometer }\end{array}$ & $\begin{array}{l}\text { Mechanical changes denture liners, } \\
\text { silver nanoparticle }\end{array}$ & $\begin{array}{l}\text { Hardness, greater } 25 \text { Sh. A, } 10 \text { ppm, } \\
40 \text { ppm }\end{array}$ \\
\hline Urban et al./2014 & $\begin{array}{c}\text { Hardness values in Shore A } \\
\text { durometer and surface roughness } \\
\text { tester }\end{array}$ & $\begin{array}{l}\text { Hardness and roughness, liners with } \\
\text { antimicrobial }\end{array}$ & $\begin{array}{l}\text { Softone roughness increased, } \\
\text { miconazole and chlorhexidine. } \\
\text { Trusoft did not increase. Hardness } \\
\text { and roughness, little changes }\end{array}$ \\
\hline
\end{tabular}


TABLE 3: Included studies related to the hardness and roughness for hard denture liners.

\begin{tabular}{|c|c|c|c|}
\hline Author/year & Method used & Study objectives & Outcomes \\
\hline Urban et al./2009 & $\begin{array}{l}\text { Vickers hardness tester and surface } \\
\text { roughness tester }\end{array}$ & $\begin{array}{c}\text { Effect of water-bath } \\
\text { postpolymerization (PP), degree of } \\
\text { conversion, flexural strength, and } \\
\text { microhardness, reline resins }\end{array}$ & $\begin{array}{l}\text { Hardness increased by PP except Ufi } \\
\text { Gel Hard }\end{array}$ \\
\hline Machado et al./2009 & $\begin{array}{l}\text { Vickers hardness tester and surface } \\
\text { roughness tester }\end{array}$ & $\begin{array}{l}\text { Hardness and surface roughness, } \\
\text { microwave and chemical } \\
\text { disinfection, reline resins, denture } \\
\text { resin }\end{array}$ & $\begin{array}{l}\text { Hardness, Lucitone 550, not affected. } \\
\text { Kooliner and DuraLiner II, increased, } \\
\text { except Lucitone 550. Microwave } 2 \\
\text { cycles, increased roughness. } \\
\text { Tokuyama did not increase. } \\
\text { Hardness, small decrease, } 30 \text { days }\end{array}$ \\
\hline Izumida et al./2014 & Surface roughness tester & $\begin{array}{l}\text { Roughness, denture cleansers, reline } \\
\text { resin }\end{array}$ & $\begin{array}{l}\text { Roughness, reduction, brushing and } \\
\text { sodium perborate and/or } \\
\text { chlorhexidine gluconate }\end{array}$ \\
\hline Machado et al./2012 & Surface roughness tester & $\begin{array}{l}\text { Roughness, denture, hard chairside } \\
\text { and resilient lining materials }\end{array}$ & $\begin{array}{l}\text { Initial roughness, no differences, } \\
\text { Lucitone and Sofreliner, Tokuyama } \\
\text { Rebase II and New Truliner. } \\
\text { Chlorhexidine } 4 \% \text {, increased } \\
\text { roughness, Ufi Gel Hard and } \\
\text { Sofreliner, after disinfection }\end{array}$ \\
\hline $\begin{array}{l}\text { Dias Panariello et } \\
\text { al./2015 }\end{array}$ & $\begin{array}{l}\text { Knoop hardness and surface } \\
\text { roughness tester }\end{array}$ & $\begin{array}{l}\text { Roughness (brushing, immersion). } \\
\text { Hardness, color, Lucitone } 550 \text { (L), } \\
\text { and reline resin }\end{array}$ & $\begin{array}{c}\text { Roughness, decreased to L. Hardness, } \\
\mathrm{NaOCl} \text { and perborate, decreased to } \\
\text { L. Hardness, decreased for T }\end{array}$ \\
\hline Machado et al./2011 & Surface roughness tester & $\begin{array}{l}\text { Roughness denture, hard chairside } \\
\text { and resilient lining materials }\end{array}$ & $\begin{array}{l}\text { Roughness, Tokuyama Rebase II and } \\
\text { Ufi Gel similar or < New Truliner. } \\
\text { Roughness, Lucitone and Tokuyama } \\
\text { Rebase II, not affected by immersion } \\
\text { and disinfection }\end{array}$ \\
\hline
\end{tabular}

TABLE 4: Included studies related to in vivo studies.

\begin{tabular}{|c|c|c|c|c|}
\hline Author/year & Observation period & Method used & Study objectives & Outcomes \\
\hline Mutlay et al./2008 & 3,6 , and 12 months & $\begin{array}{l}\text { Evaluation criteria: physical } \\
\text { integrity, surface detail, } \\
\text { adhesion, color, odor, plaque } \\
\text { accumulation, resilience, } \\
\text { hygiene, mucosal condition, } \\
\text { and signs of fungal } \\
\text { colonization }\end{array}$ & $\begin{array}{c}\text { Clinical performance } \\
\text { denture liners, } 12 \text { months }\end{array}$ & $\begin{array}{l}\text { Roughening, posterior } \\
\text { region }\end{array}$ \\
\hline Bail et al./2014 & $\begin{array}{l}\text { Rats used palatal plates, } 14 \\
\text { days }\end{array}$ & A roughness tester & Roughness, soft liners & $\begin{array}{l}\text { Roughness, Dentuflex and } \\
\text { Dentusoft, similar. Trusoft, } \\
\text { rougher than Dentusoft. Ufi } \\
\text { Gel P, lowest roughness } \\
\text { (14-day) }\end{array}$ \\
\hline Ogawa et al/2016 & $\begin{array}{l}\text { Original and 1-month } \\
\text { hardness, after oral exposure }\end{array}$ & Shore D hardness & $\begin{array}{l}\text { Denture liners changes, } \\
\text { 1-month clinical setting }\end{array}$ & $\begin{array}{c}\text { Hardness, changes } \\
\text { influenced, patients' } \\
\text { characteristics }\end{array}$ \\
\hline
\end{tabular}

Considering experimental urethane acrylate oligomersbased photopolymerized soft liners, no significant difference in adhesion was observed after 1 day or 12 months of storage in water at $37^{\circ} \mathrm{C}$ [34]. This material seems to increase the liners' durability, which is usually of a few months.

4.1.3. Liners' Adhesion to Different Types of Prostheses. To improve bonding between polyamide prostheses and selfpolymerizable resin liners, the prosthesis treatment with tribochemical silica and 4-META/MMA-TBB (4-methacryloxyethyl trimellitate anhydride in methylmethacrylate initiated by tri-n-butyl borane) resin is recommended [36]. Polyamides are chemical resistant materials due to their high degree of crystallinity [33].

Ahmad et al. [1] found flaws in the liners' adhesion to a UDMA (photopolymerized urethane dimethacrylate) prosthesis due to its highly reticular nature that hinders the monomer penetration. In contrast, Akin et al. [53] found similar adhesion of the resilient liner to UDMA or PMMA 
prostheses. Adhesion of hard liners to thermoplastic acrylic resin was similar to that of conventional thermopolymerized acrylic resin; however, results were different for polyamide since these polymers are chemically resistant [33].

A weak adhesion between the resilient resin-base liner and prothesis was explained by the absence of monomers associated with nonreticulated amorphous polymers [50]. Nonetheless, glass fiber-reinforced PMMA showed increased adhesion to the liner since the fibers were previously filled with nonreticulated polymers containing PMMA islands in micrometric scale [12]. These exposed fibers were better dissolved by ethyl acetate.

4.1.4. Antimicrobial Agents. It is important to assess changes in adhesion of prostheses and liners resulting from medicine incorporation. Antimicrobial additives can be a low-cost, effective alternative that does not require the patients' cooperation [12]. Pisani et al. [54] showed no changes in resin liner bonding considering immersion time or sodium perborate use, indicating that these do not affect the materials' dissolution. Alcântara et al. [55] showed that the addition of nystatin, miconazole, ketoconazole, or chlorhexidine diacetate in several dosages had no effect on the liner's adhesion to the prosthesis.

4.1.5. Considerations Relative to Denture Liners' Adhesion. Poor adhesion creates a favorable environment to microorganisms and compromises the liner's durability. For silicone liners, the use of solvents seems to improve their adhesion to PMMA, since it favors the adhesive penetration and creates a mechanical blockage. For PMMA surfaces, the substitution of the most commonly found monomer (acetone and 2HEMA) for a solution with better agent evaporation improves adhesion allowing the interlocking of the polymer chains.

4.2. Surface Roughness. There are several methods to remove contaminants from the liners, but it is important to assess their effects on the surface since cleaning solutions can penetrate the resin and change its morphology. In addition, immersion time and concentration can alter the polymer structure [32].

Self-polymerizable hard liners' roughness increases after immersion in sodium perborate and radiation with microwaves due to the immersion temperature and oxygen release by the perborate [17]. Bubbling from the oxygen release is a mechanical cleaning mechanism [17]. Izumida et al. [32] found a reduction in roughness associated with brushing and disinfection with sodium perborate and/or chlorhexidine gluconate and related it to cross-linked agents that reduce the acrylic resin solubility in organic solvents.

Brushing with only toothpaste and water increased roughness of silicone liner [32, 37], since toothpaste is composed of sodium carbonate, an abrasive agent.

No changes in roughness were found in one heatpolymerized denture base acrylic resin (Lucitone 550b) and another autopolymerized reline resin (Tokuyama Rebase Fast II) with different cleaning agents and this was associated with the short immersion time $(1,3,21,45$, and 90 cycles of 10 seconds) [56]. Machado et al. [44] found an increase in roughness of the hard liner due to porosities formed from the release of residual monomers and plasticizers and from the increase in temperature during disinfection with microwaves. The increase in roughness was observed when organic solvents such as MMA were applied on PMMA as an attempt to improve adhesiveness to silicone-based liners [35], because these solvents degrade the surface and alter its morphology.

Values found for roughness of resin and silicone liners [22] exceeded the ideal clinical parameter $(0.2 \mu \mathrm{m})$ [57]. High values were also found by other authors [27, 44, 58]. Kutlu et al. [28] prepared the specimens on glass plates and obtained values above $0.2 \mu \mathrm{m}$. Machado et al. [58] found initial roughness of $3.54 \mu \mathrm{m}$ in a resin-base liner. Methacrylate resilient liners are rougher than silicone liners due to their chemical structure, residual monomer content, polymerization method, monomers' volatility, and mixing technique $[24,43]$.

4.2.1. Sealants' Application. Surface sealants protect liners against water absorption and damage from chemicals, saliva, food, and brushing and coating defects and reduce porosities and fissures [18, 29]. Their application reduced roughness produced by brushing in silicone and resin liners, with a more pronounced effect for siloxane-based material [18]. On the other hand, Kutlu et al. [28] showed no reduction in roughness when a sealant was applied to silicone-based and methacrylate-based liners. These findings are in agreement with another study [43]. Several situations increase liners' roughness, a favoring factor for bacteria accumulation. There is still no consensus on whether roughness is reduced when a surface sealant is applied.

4.3. Hardness. According to the specific ISO standards, liners can be categorized as type A (soft) or type B (extra soft) for measurements taken 24 hours after the preparation of specimens (ISO 10139-2:2009) [59].

A compilation associated with resilient liners comprises changes in hardness over time [42]. Hardness can be defined as penetration resistance [10], it increased in resin liners subjected to warm-water bath following polymerization, and it was associated with the reduction in residual monomers [6]. Mancuso et al. [60] also found an increase after aging that was associated with differences in type and content of plasticizers, leaching, and liquid absorption [17, 60]. Hardness of experimental photopolymerizable soft liners based on urethane acrylate oligomers was similar to that of silicone or acrylic resilient liners [34]. Conversely, Cazacu et al. [45] found higher hardness values for a thermostable silicone tested as liner, equivalent to that of addition silicone.

Chemical cleaning is the first choice to avoid liner damage. Immersion impacts malleability, ductility, and resistance to traction [19]. Immersion in different solutions increased the liners' hardness $[17,44,46]$. On the other hand, RezendePinto et al. [27] found a reduction in self-polymerizable hard liners' hardness regardless of chemical solution or water immersion, before and after 30 cycles. Water diffuses through 
the resin until it saturates it and this results in surface softening.

Clinically, changes in hardness can also be caused by temperature fluctuations in the oral cavity and changes in $\mathrm{pH}$ [29], and, in the laboratory, they may still be affected by the type and concentration, immersion time, and composition of the cleaning solution. Changes in acrylic resilient liners occurred after 1 month of use by patients; and smoking patients showed higher hardness values, probably due to heat exposure. The frequent use of cleaners kept the liners soft and delayed their hardening process. Complete maxillary prostheses users presented higher values, associated with the materials' package. It is known that the pressure exerted by the denture during mastication accelerates the liner degradation. Complete monomaxillary prostheses exert greater occlusal strength than the bimaxillary prostheses. However, the authors showed no association between hardness and occlusal force after 1 month of the liner application. An increase in saliva acidity was associated with an increase in hardness, but this association cannot be generalized. Finally, use during sleep increased hardness, which was associated with individual and environmental factors [42].

Maintenance of materials' hardness is critical for their longevity; its effect, with and without sealants, varied among studies [18, 29]. Sealant application on resilient methacrylate can be effective in preserving hardness, since the solvent evaporates and creates a superficial layer resistant to degradation [29].

Given that soft liners' hardness is approximately 40 Shore hardness units (DIN 53505 and ASTM D2240/75), Santawisuk et al. [25] have enhanced the mechanical properties of an experimental silicone by adding synthetic silica. Comparing with silicone liners, it showed potential as a liner (Shore A hardness 41.3). Kasuga et al. [8] tested a fluorinated monomer of dodecafluoroheptyl methacrylate as soft liner material and observed Shore A hardness, similar to that of a commercially available silicone-based liner.

According to Izumida et al. [32], materials containing reticulation agents show greater stability in hardness when stored in aqueous solutions. Pisani et al. [48], on the other hand, found a hardness increase of both liners when stored in liquids. Hypochlorite was the solution that resulted in the greatest change.

Authors also failed to find significant changes when incorporating antimicrobial agents [61]. Chladek et al. [62] found no alterations in a silicone liner with the incorporation of silver nanoparticles in concentrations of up to $40 \mathrm{ppm}$. From $80 \mathrm{ppm}$, hardness and resistance to traction were considerably reduced.

It should be noted that the hardness has a direct relation with the viscoelastic properties which are responsible for distributing and absorbing the tensions generated during its clinical function $[15,19,20]$. The higher the hardness value, the lower the material's ability to absorb the impact of mastication [37]. Decrease in hardness values may lead to superficial changes and retention of oral pathogens. In addition, the silicone rubber-based soft lining materials enhance the growth of fungi such as Candida albicans on the presence of saliva $[63,64]$.

\section{General Considerations}

Failure of adhesion between the prosthesis and liner will compromise the procedure durability and favor microbial colonization. Adhesive failure may be associated with the bonding agent. The use of solvents in silicone-based liners seems to improve the adhesion of these to the PMMA base. A surface treatment is required to adhere liners to the polyamide denture base, either with acetic acid or with tribochemical silica. For PMMA surfaces, better adhesion is obtained with the same chemical properties of the liner and denture base. It is important to preserve the hardness values, so that the liner can maintain its elastic property.

Roughness surfaces and hardness changes favor microbial colonization and stomatitis. The selection of the liner should be based on the procedure's objective, considering serviceability, and expected results. The diversity of methods presented the properties in a diverse manner, showing that subsequent studies are necessary to meet better utilization and indication of liners regarding hardness, roughness, and adhesion. Based on the present results, further in vivo investigations with randomized controlled trials are necessary to compare the performance and properties of these denture liners' modifications in clinical use.

\section{Conflicts of Interest}

The authors report no conflicts of interest.

\section{References}

[1] F. Ahmad, M. Dent, and N. Yunus, "Shear bond strength of two chemically different denture base polymers to reline materials," Journal of Prosthodontics, vol. 18, no. 7, pp. 596-602, 2009.

[2] F. Valentini, M. Luz, N. Boscato, and T. Pereira-Cenci, "Surface roughness changes in denture liners in denture stomatitis patients," The International Journal of Prosthodontics, vol. 30, no. 6, pp. 561-564, 2017.

[3] E. S. Rosenberg, J. P. Torosian, and J. Slots, "Microbial differences in 2 clinically distinct types of failures of osseointegrated implants," Clinical Oral Implants Research, vol. 2, no. 3, pp. 135144, 1991.

[4] A. Mombelli and N. P. Lang, "The diagnosis and treatment of peri-implantitis," Periodontology 2000, vol. 17, no. 1, pp. 63-76, 1998.

[5] T. Matsuura, Y. Abe, Y. Sato, K. Okamoto, M. Ueshige, and Y. Akagawa, "Prolonged antimicrobial effect of tissue conditioners containing silver-zeolite," Journal of Dentistry, vol. 25, no. 5, pp. 373-377, 1997.

[6] V. M. Urban, A. L. Machado, C. E. Vergani et al., "Effect of water-bath post-polymerization on the mechanical properties, degree of conversion, and leaching of residual compounds of hard chairside reline resins," Dental Materials, vol. 25, no. 5, pp. 662-671, 2009.

[7] E. B. Moffa, E. T. Giampaolo, F. E. Izumida, A. C. Pavarina, A. L. MacHado, and C. E. Vergani, "Colour stability of relined 
dentures after chemical disinfection. A randomised clinical trial," Journal of Dentistry, vol. 39, no. 3, pp. e65-e71, 2011.

[8] Y. Kasuga, H. Takahashi, N. Akiba, S. Minakuchi, N. Matsushita, and M. Hishimoto, "Basic evaluation on physical properties of experimental fluorinated soft lining materials," Dental Materials, vol. 30, no. 1, pp. 45-51, 2011.

[9] G. A. Zarb, G. E. Carlsson, and C. L. Bolender, "Bouchers prosthodontic treatment for edentulous patients," pp. 144-149, Mosby, St., Louis, 11th edition, 2013.

[10] K. J. Anusavice, C. Shen, and H. R. Rawls, "Phillips' science of dental materials," in Elsevier Health Sciences, pp. 492-494, 12th edition, 2012.

[11] M. Saravanan, V. Kumar, T. Padmanabhan, and F. Banu, "Viscoelastic properties and antimicrobial effects of soft liners with silver zeolite in complete dental prosthesis wearers: an in vivo study," The International Journal of Prosthodontics, vol. 28, no. 3, pp. 265-269, 2016.

[12] L. V. J. Lassila, M. M. Mutluay, A. Tezvergil-Mutluay, and P. K. Vallittu, "Bond strength of soft liners to fiber-reinforced denture-base resin," Journal of Prosthodontics, vol. 19, no. 8, pp. 620-624, 2010.

[13] H.-S. Cha, B. Yu, and Y.-K. Lee, "Changes in stress relaxation property and softness of soft denture lining materials after cyclic loading," Dental Materials, vol. 27, no. 3, pp. 291-297, 2011.

[14] A. M. Dimiou, K. Michalakis, and A. Pissiotis, "Influence of thickness increase of intraoral autopolymerizing hard denture base liners on the temperature rise during the polymerization process," Journal of Prosthetic Dentistry, vol. 111, no. 6, pp. 512$520,2014$.

[15] W. Więckiewicz, J. Kasperski, M. Więckiewicz, M. Miernik, and W. Król, "The adhesion of modern soft relining materials to acrylic dentures," Advances in Clinical and Experimental Medicine, vol. 23, no. 4, pp. 621-625, 2014.

[16] C. D. A. L. Chaves, A. L. MacHado, I. Z. Carlos, E. T. Giampaolo, A. C. Pavarina, and C. E. Vergani, "Cytotoxicity of monomers, plasticizer and degradation by-products released from dental hard chairside reline resins," Dental Materials, vol. 26, no. 10, pp. 1017-1023, 2010.

[17] A. L. Machado, L. C. Breeding, C. E. Vergani, and L. E. da Cruz Perez, "Hardness and surface roughness of reline and denture base acrylic resins after repeated disinfection procedures," The Journal of Prosthetic Dentistry, vol. 102, no. 2, pp. 115-122, 2009.

[18] V. C. Mainieri, J. Beck, H. M. Oshima, L. M. Hirakata, and R. S. Shinkai, "Surface changes in denture soft liners with and without sealer coating following abrasion with mechanical brushing," Gerodontology, vol. 28, no. 2, pp. 146-151, 2011.

[19] A. Mese and K. G. Guzel, "Effect of storage duration on the hardness and tensile bond strength of silicone- and acrylic resin-based resilient denture liners to a processed denture base acrylic resin," Journal of Prosthetic Dentistry, vol. 99, no. 2, pp. 153-159, 2008.

[20] S. Atsü and Y. KeskIn, "Effect of silica coating and silane surface treatment on the bond strength of soft denture liner to denture base material," Journal of Applied Oral Science, vol. 21, no. 4, pp. 300-306, 2013.

[21] W.-C. Liao, G. J. Pearson, M. Braden, and P. S. Wright, "The interaction of various liquids with long-term denture soft lining materials," Dental Materials, vol. 28, no. 10, pp. e199-e206, 2012.

[22] F. Valentini, M. S. Luz, N. Boscato, and T. Pereira-Cenci, "Biofilm formation on denture liners in a randomised controlled in situ trial," Journal of Dentistry, vol. 41, no. 5, pp. 420427, 2013.
[23] A. Nowakowska-Toporowska, Z. Raszewski, and W. Wieckiewicz, "Color change of soft silicone relining materials after storage in artificial saliva," The Journal of Prosthetic Dentistry, vol. 115, no. 3, pp. 377-380, 2016.

[24] M. Bail, J. H. Jorge, V. M. Urban, and N. H. Campanha, "Surface roughness of acrylic and silicone-based soft liners: in vivo study in a rat model," Journal of Prosthodontics, vol. 23, no. 2, pp. 146151,2014

[25] W. Santawisuk, W. Kanchanavasita, C. Sirisinha, and C. Harnirattisai, "Mechanical properties of experimental silicone soft lining materials," Dental Materials, vol. 32, no. 6, pp. 970-975, 2013.

[26] International Organization for Standardization, Dentistry-Soft Lining Materials for Removable Dentures Part 2: Materials for Long-Term Use, ISO/FDIS 10139-2, Switzerland, 1999.

[27] L. de Rezende Pinto, E. J. T. R. Acosta, F. F. F. Távora, P. M. B. Da Silva, and V. C. Porto, "Effect of repeated cycles of chemical disinfection on the roughness and hardness of hard reline acrylic resins," Gerodontology, vol. 27, no. 2, pp. 147-153, 2010.

[28] I. Usta Kutlu, N. D. Yanikoğlu, E. Kul, Z. Y. Duymuş, and N. P. Sağsöz, "Effect of sealer coating and storage methods on the surface roughness of soft liners," The Journal of Prosthetic Dentistry, vol. 115, no. 3, pp. 371-376, 2016.

[29] F. K. Mante, M. O. Mante, and V. C. Petropolous, "In vitro changes in hardness of sealed resilient lining materials on immersion in various fluids," Journal of Prosthodontics, vol. 17, no. 5, pp. 384-391, 2008.

[30] T. Ohkubo, M. Oizumi, and T. Kobayashi, "Influence of methylmercaptan on the bonding strength of autopolymerizing reline resins to a heat-polymerized denture base resin," Dental Materials, vol. 28, no. 4, pp. 426-432, 2009.

[31] J. M. F. K. Takahashi, R. L. X. Consani, G. E. P. Henriques, M. A. de Arruda Nóbilo, and M. F. Mesquita, "Effect of accelerated aging on permanent deformation and tensile bond strength of autopolymerizing soft denture liners," Journal of Prosthodontics, vol. 20, no. 3, pp. 200-204, 2011.

[32] F. E. Izumida, J. H. Jorge, R. C. Ribeiro, A. C. Pavarina, E. B. Moffa, and E. T. Giampaolo, "Surface roughness and Candida albicans biofilm formation on a reline resin after long-term chemical disinfection and tooth brushing," Journal of Prosthetic Dentistry, vol. 112, no. 6, pp. 1523-1529, 2014.

[33] B.-J. Kim, H.-S. Yang, M.-G. Chun, and Y.-J. Park, "Shore hardness and tensile bond strength of long-term soft denture lining materials," Journal of Prosthetic Dentistry, vol. 112, no. 5, pp. 1289-1297, 2014.

[34] T. Kanie, K. Tomita, M. Tokuda, H. Arikawa, K. Fujii, and S. Ban, "Mechanical properties and cytotoxicity of experimental soft lining materials based on urethane acrylate oligomers," Dental Materials, vol. 28, no. 4, pp. 501-506, 2009.

[35] Y. W. Cavalcanti, M. M. Bertolini, A. A. Del Bel Cury, and W. J. Da Silva, "The effect of poly(methyl methacrylate) surface treatments on the adhesion of silicone-based resilient denture liners," Journal of Prosthetic Dentistry, vol. 112, no. 6, pp. 15391544, 2014.

[36] I. Hamanaka, H. Shimizu, and Y. Takahashi, "Bond strength of a chairside autopolymerizing reline resin to injection-molded thermoplastic denture base resins," Journal of Prosthodontic Research, vol. 61, no. 1, pp. 67-72, 2017.

[37] M. M. Badaró, T. P. Prates, V. M. Leite-Fernandes, V. d. Oliveira, H. d. Paranhos, and C. H. Silva-Lovato, "In vitro 
evaluation of resilient liner after brushing with conventional and experimental," Journal of Prosthodontics, vol. 28, no. 2, pp. e857-e862, 2019.

[38] D. Moher, A. Liberati, J. Tetzlaff, D. G. Altman, and PRISMA Group, "Preferred reporting items for systematic reviews and meta-analyses: the PRISMA statement," Journal of Clinical Epidemiology, vol. 62, no. 10, pp. 1006-1012, 2009.

[39] A. Liberati, D. G. Altman, J. Tetzlaff et al., "The PRISMA statement for reporting systematic reviews and meta-analyses of studies that evaluate health care interventions: explanation and elaboration," PLoS Medicine, vol. 6, Article ID e1000100, pp. 1-28, 2009.

[40] J. H. Kim, H. C. Choe, and M. K. Son, "Evaluation of adhesion of reline resins to the thermoplastic denture base resin for nonmetal clasp denture," Dental Materials, vol. 33, no. 1, pp. 32-38, 2014.

[41] M. M. Mutluay, S. Oguz, F. Fløystrand et al., "A prospective study on the clinical performance of polysiloxane soft liners: one-year results," Dental Materials, vol. 27, no. 3, pp. 440-447, 2008.

[42] A. Ogawa, S. Kimoto, H. Saeki, M. Ono, N. Furuse, and Y. Kawai, "The influence of patient characteristics on acrylicbased resilient denture liners embedded in maxillary complete dentures," Journal of Prosthodontic Research, vol. 60, no. 3, pp. 199-205, 2016.

[43] A. Dayrell, J. Takahashi, G. Valverde, R. Consani, G. Ambrosano, and M. Mesquita, "Effect of sealer coating on mechanical and physical properties of permanent soft lining materials," Gerodontology, vol. 29, no. 2, pp. e401-e407, 2012.

[44] A. L. MacHado, E. T. Giampaolo, A. C. Pavarina, J. H. Jorge, and C. E. Vergani, "Surface roughness of denture base and reline materials after disinfection by immersion in chlorhexidine or microwave irradiation," Gerodontology, vol. 29, no. 2, pp. e375e382, 2012.

[45] M. Cazacu, C. Racles, A. Vlad, M. Antohe, and N. Forna, "Silicone-based composite for relining of removable dental prosthesis," Journal of Composite Materials, vol. 43, no. 19, pp. 2045-2055, 2009.

[46] J. M. Takahashi, F. M. Machado, J. M. Nuñez, R. L. Consani, and M. F. Mesquita, "Relining of prosthesis with auto-polymerizing hard denture reline resins: effect of post-polymerization treatment on flexural strength," Gerodontology, vol. 26, no. 3, pp. 232-236, 2009.

[47] V. M. F. Leite, M. X. Pisani, H. F. O. Paranhos, R. F. Souza, and C. H. Silva-Lovato, "Effect of ageing and immersion in different beverages on properties of denture lining materials," Journal of Applied Oral Science, vol. 18, no. 4, pp. 372-378, 2010.

[48] M. X. Pisani, C. H. L. Da Silva, H. F. O. Paranhos, R. F. Souza, and A. P. MacEdo, "Evaluation of experimental cleanser solution of Ricinus communis: Effect on soft denture liner properties," Gerodontology, vol. 29, no. 2, pp. e179-e185, 2012.

[49] Y. Tanimoto, H. Saeki, S. Kimoto, T. Nishiwaki, and N. Nishiyama, "Evaluation of adhesive properties of three resilient denture liners by the modified peel test method," Acta Biomaterialia, vol. 5, no. 2, pp. 764-769, 2009.

[50] T. Maeda, G. Hong, S. Sadamori, T. Hamada, and Y. Akagawa, "Durability of peel bond of resilient denture liners to acrylic denture base resin," Journal of Prosthodontic Research, vol. 56, no. 2, pp. 136-141, 2012.

[51] R. Osathananda and C. Wiwatwarrapan, "Surface treatment with methyl formate-methyl acetate increased the shear bond strength between reline resins and denture base resin," Gerodontology, vol. 33, no. 2, pp. 147-154, 2016.

[52] R. Koodaryan and A. Hafezeqoran, "Effect of surface treatment methods on the shear bond strength of auto-polymerized resin to thermoplastic denture base polymer," The Journal of Advanced Prosthodontics, vol. 8, no. 6, pp. 504-510, 2016.

[53] H. Akin, F. Tugut, U. Guney, O. Kirmali, and T. Akar, “Tensile bond strength of silicone-based soft denture liner to two chemically different denture base resins after various surface treatments," Lasers in Medical Science, vol. 28, no. 1, pp. 119-123, 2013.

[54] M. X. Pisani, C. H. Silva-Lovato, A. D. L. Malheiros-Segundo, A. P. MacEdo, and H. F. O. Paranhos, "Bond strength and degree of infiltration between acrylic resin denture liner after immersion in effervescent denture cleanser," Journal of Prosthodontics, vol. 18, no. 2, pp. 123-129, 2009.

[55] C. S. Alcântara, A. F. C. de Macêdo, B. C. V. Gurgel, J. H. Jorge, K. H. Neppelenbroek, and V. M. Urban, "Peel bond strength of resilient liner modified by the addition of antimicrobial agents to denture base acrylic resin," Journal of Applied Oral Science, vol. 20, no. 6, pp. 607-612, 2012.

[56] B. H. D. Panariello, F. E. Izumida, E. B. Moffa, A. C. Pavarina, J. H. Jorge, and E. T. Giampaolo, "Effects of short-term immersion and brushing with different denture cleansers on the roughness, hardness, and color of two types of acrylic resin," American Journal of Dentistry, vol. 28, no. 3, pp. 150-156, 2015.

[57] C. M. Bollen, P. Lambrechts, and M. Quirynen, "Comparison of surface roughness of oral hard materials to the threshold surface roughness for bacterial plaque retention: a review of the literature," Dental Materials, vol. 13, no. 4, pp. 258-269, 1997.

[58] A. L. Machado, E. T. Giampaolo, C. E. Vergani, J. F. de Souza, and J. H. Jorge, "Changes in roughness of denture base and reline materials by chemical disinfection or microwave irradiation: surface roughness of denture base and reline materials," Journal of Applied Oral Science, vol. 19, no. 5, pp. 521-528, 2011.

[59] International Organization for Standardization, ISO 101392:2009. Dentistry e Soft lining materials for removable dentures Part 2: Materials for long-term use, Geneva, 2009, https://www.iso.org/store.html.

[60] D. N. Mancuso, M. C. Goiato, B. C. R. Zuccolotti, A. Moreno, D. M. Dos Santos, and A. A. Pesqueira, "Effect of thermocycling on hardness, absorption, solubility and colour change of soft liners," Gerodontology, vol. 29, no. 2, pp. e215-e219, 2012.

[61] M. M. Bertolini, M. B. Portela, J. A. R. Curvelo, R. M. A. Soares, E. J. V. Lourenço, and D. M. Telles, "Resins-based denture soft lining materials modified by chlorhexidine salt incorporation: An in vitro analysis of antifungal activity, drug release and hardness," Dental Materials, vol. 30, no. 8, pp. 793-798, 2014.

[62] G. Chladek, J. Kasperski, I. Barszczewska-Rybarek, and J. Zmudzki, "Sorption, solubility, bond strength and hardness of denture soft lining incorporated with silver nanoparticles," International Journal of Molecular Sciences, vol. 14, no. 1, pp. 563-574, 2013.

[63] P. S. Wright, P. Clark, and J. M. Hardie, "The prevalence and significance of yeasts in persons wearing complete dentures with soft-lining materials," Journal of Dental Research, vol. 64, no. 2, pp. 122-125, 1985.

[64] D. R. Radford, S. J. Challacombe, and J. D. Walter, “Denture plaque and adherence of Candida albicans to denture-base materials in vivo and in vitro," Critical Reviews in Oral Biology and Medicine, vol. 10, no. 1, pp. 99-116, 1999. 


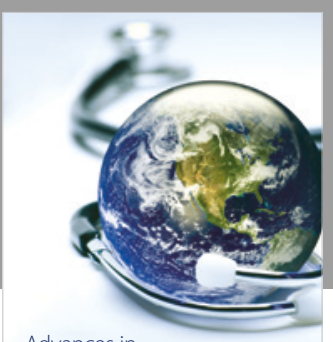

Advances in
Public Health

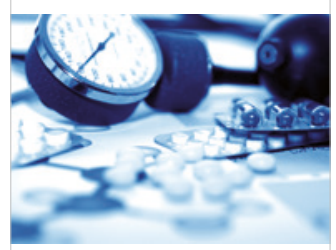

Case Reports in

Medicine

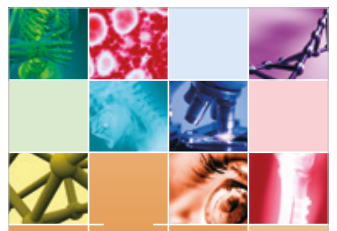

niernational Journal of

Biomaterials
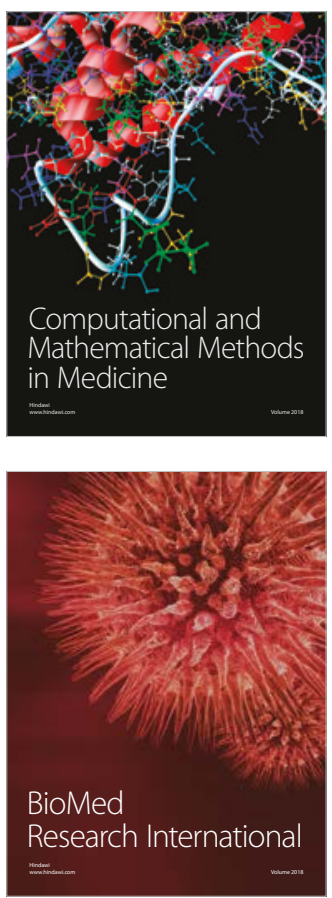

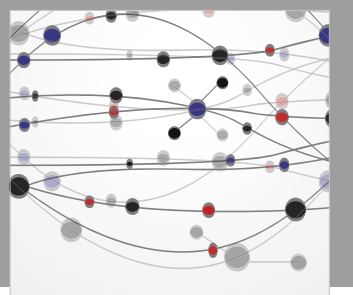

The Scientific World Journal Dentistry

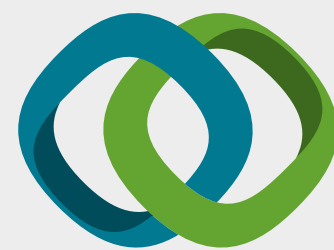

Hindawi

Submit your manuscripts at

www.hindawi.com
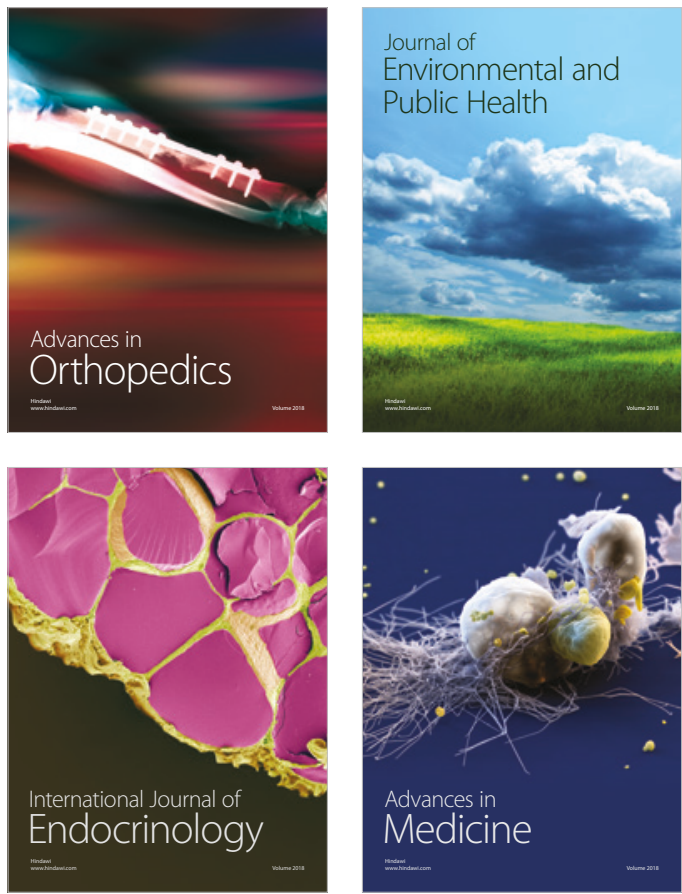
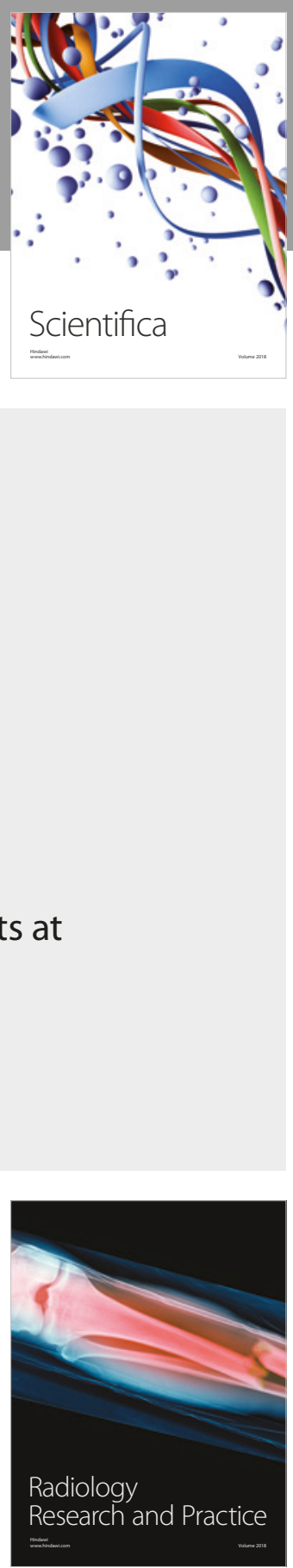

Scientifica

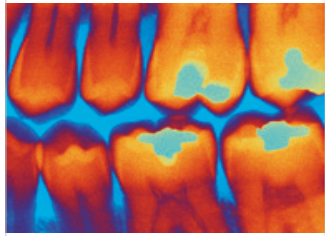

Case Reports in

Dentistry
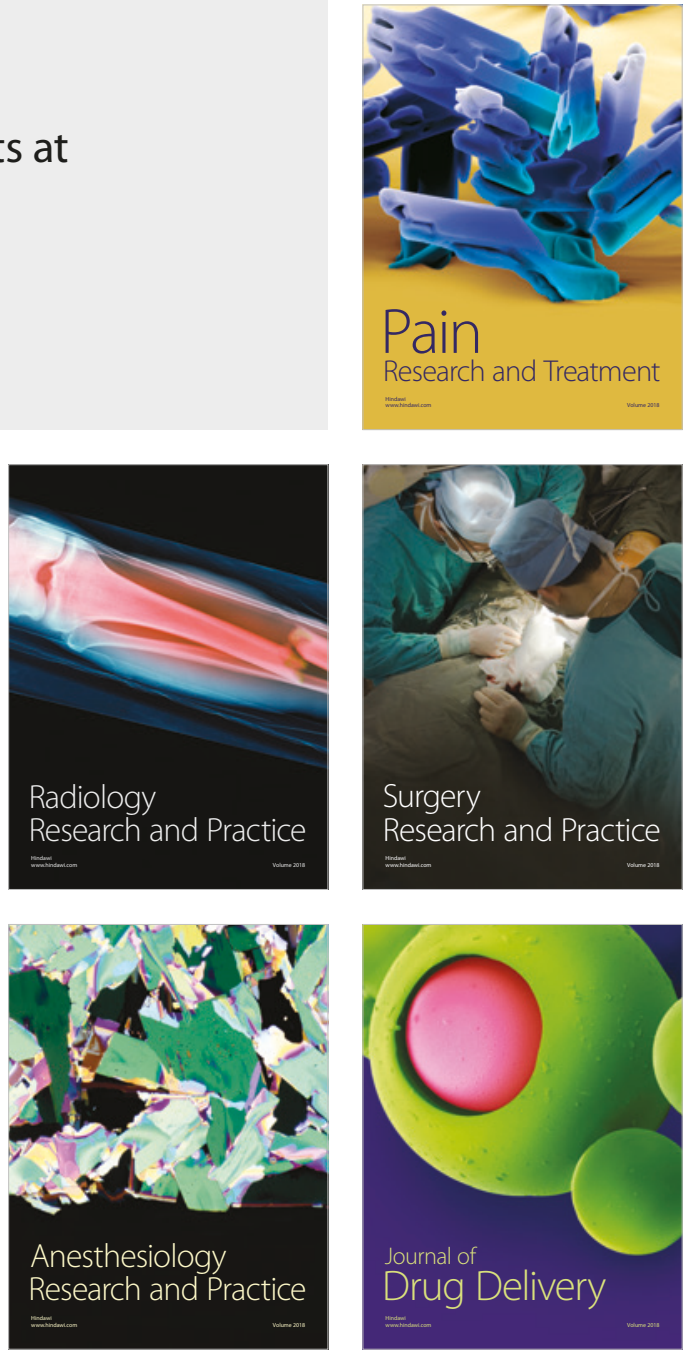